【総説】

\section{音楽療法の現状 \\ Current Status of Music Therapy}

\author{
板 東浩 $1,2^{*}$ \\ Hiroshi BANDO ${ }^{1,2 *}$ \\ 1 日本音楽療法学会評議員 \\ 2 日本抗加齢医学会評議員
}

\section{【要 旨】}

現在, 補完代替医療 (CAM) の一つとして音楽療法 (music therapy, MT) が注目されている. 同療法には広 義でレクリエーションなどを主とする音楽健康法と, 狭義で治療の視点を有する狭義の音楽療法がある. セッションにより単に良くなったという判断は不十分 で，何らかの評価法で改善したというエビデンスや効 果の判定が必要となる。音楽を聴取する受容的音楽療 法と, カラオケなどの歌唱や楽器演奏などを行う能動 的音楽療法に大別される. 対象者としては, 小児や精 神疾患患者, 高齢者, 認知症などがあり, 本邦では高 齢者対象の場合が多く，ニードが高い，高齢者では認 知レベルや QOL, ADL の変化を評価し, 療法の効果を 判定すべきである. 近年 MT と他の CAM との併用が 行われ，行政の見地からも，展開する余地が残されて いる. 今後は CAM の中でMT の重要性が増し, evidence-based MT ならびに narrative-based MT の両 者で研究の発展が望まれる.

【キーワード】

音楽療法, 補完代替医療, リハビリテーション, 高齢 者, 認知症
はじめに

近年, 補完代替医療 (Complementary and Alternative Medicine, CAM) が注目を浴び，欧米では CAM が次第に 認知されつつある。米国の国立衛生研究所 (NIH) では研 究部が設置され, 主要な医学校でもカリキュラムにCAM が含ま机てきている. 本邦でも, 当学会 (Japanese Society for CAM)の活動などにより，CAM の理解が広まってき た.

CAM の一つに音楽療法 (music therapy) があり, いま社 会で多くの関心を呼び，ジャーナリズムでもしばしば取 り上げられている. 医療福祉の領域でも, 音楽療法のニ一 ズが高まっているのは，音楽療法が多くの人々に受け入 れられやすいからであろら。音楽は誰もが好きであり， 心身の健康に活用できれば望ましい，音楽療法の領域は 幅広く，そのレベルもさまざまである，全体を把握しゃ すくするため，2つに大別してみたい．

一つは広義の音楽療法であり, レクリエーションなど を主とする音楽健康法に近い内容である。音楽や医療の 専門家でなくても，誰もが日常的に，ストレスの解消に 音楽で心を癒しているものだ，気持ちよくなった，楽し くなった，といら気分を感じれば，効いたと思う。

他方は, 治療の視点を有する狭義の音楽療法である. 音楽といら治療を施行し，どのように変化したのか，き ちんと評価する必要がある。単に良くなったという表現 では不十分で, 何らかの評価法で改善したというエビデ ンスや，効果を判定しなければならない。

本稿では, 音楽療法について概説する. その際, 教科 書的な記載ではなく, 最近のトピックスや関連する領域 として芸術, 文化, 医療, 行政などとの係わりもあわせ， いろいろな切り口から記させていただきたい。

\section{1. 芸術と科学}

しばしば，芸術と科学とは対立する存在と考兄られて きた. 日本音楽療法学会の日野原重明理事長も, 従来アー トとサイエンスについて論じている。つまり，Art vs Science に相当するものとして, 医療 vs 医学, 患者 vs 疾 病, 技 vs 知識, 癌の告知 vs 癌の診断といら例を示すと, わかりやすいだろう。ただし，実際の医療現場では，両 者を融合させて，患者に応じて対処する必要がある，

それでは，歴史的な内容から，説明していきたい。ギ

受理日：2008 年 1 月 4 日

* 干770-0943 徳島市中昭和町1-61 Tel: 090-3187-2485 Fax: 088-645-2032,088-654-3945 E-mail: pianomed@bronze.ocn.ne.jp URL: http://hb8.seikyou.ne.jp/home/pianomed/ 
リシアの哲学者といえば, 三人の有名な哲人が存在する。 ソクラテス・プラトン・アリストテレスといら流れによっ て，西洋哲学の基礎が築かれた（図 1).

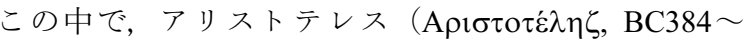
BC322, Aristotle, 英語読みでアリストートル) は, 人の生 命や文化，芸術，科学，音楽について解釈を試みた。命 や霊魂のことをギリシア語で「プシケー (psyke)」と呼び, この言葉から心理学(psycology)括よび精神科 (psychiatry) が派生する. 彼は，大自然を四階建てのピラミッドとし て描いた。 1 階には，プシケのない地・水・火・風を，二 階以上にはプシケを有するものとして, 二階に植物, 三 階に動物を配置. 4 階には人間と, 順番に積み重ねた. 植 物は栄養一生殖, 動物は感覚一運動, 人は理解一意志と いら機能を持ち, ピラミッド頂点の人間の理性が, 生物 進化の究極の目標とした.

また，アリストテレスは，すべての事象が目的をもっ て営まれていると考えた. 生物に機能があり多様性があ るのは，何らかの目的があるためだと論じたのである。 音楽に関連して，心のカタルシス（浄化）といら斬新な 考え方を示した．これが，後述する音楽療法の原則「同 質の原理」へ展開していくことになる.

その後，イギリスの自然科学者のダーウィン (Charles Robert Darwin, 1809〜1882) が登場する（図 2). 彼は進化 論を唱え, 生物が獲得した機能は自然選択の結果とした。

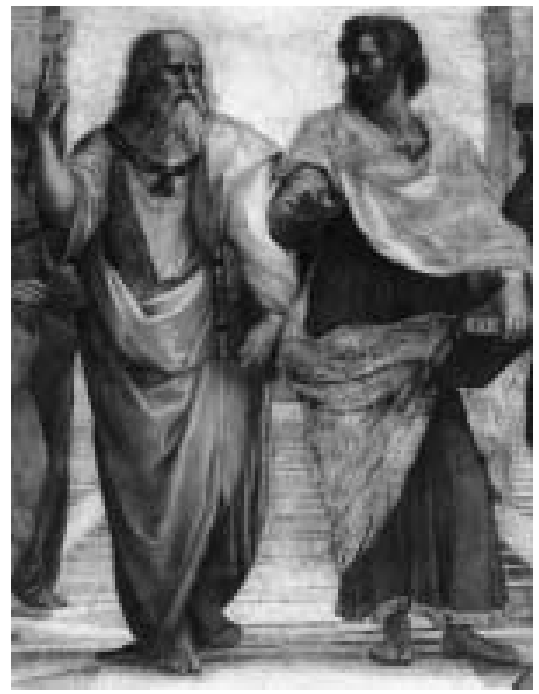

図 1 プラトン（左）とアリストテレス（右）
進化が目的を有していないと解釈するため，アリストテ レスの考え方と対峙することになる，ダーウィンは，進 化論に加えて, 音楽や美術, 文学の才能，人間の脳の構 造，精神などについても，自然選択によって説明が可能 であると考えていた

音楽の存在意義を考えてみると，何か特別な目的があ るから音楽があるのではないであろら。むしろ，何かの きっかけにより，音や声，コミュニケーションから音楽 が生まれた。音楽の存在を認識した後，音楽のパワーや 効用が次第に明らかになってきたと思われる.

音楽の対立軸として，文字を挙げたい，人は他の動物 と異なり，コミュニケーションを行ってきた．その内容 を文化に変換して伝えたいといら衝動が生まれてくる. その目的のために文字が発明され，世代を超えて伝達さ れていく，人を突き動かす衝動や欲望こそが，人におけ る脳の進化なのかもしれない2).

\section{2. 音楽と科学}

芸術には絵画や音楽があり, 科学には数学や天文学が 含まれているのは，誰もが納得するだろう。しかしなが ら，「かつて，音楽は科学だった」と論じれば，不思議に 感じるのではなかろらか

西洋音楽の歴史をたどると，音楽と科学とは一体と なって論じられていた。音楽に対して，数学や物理学を 用いて科学的に研究するのが常識であった時代が，18 世 紀ごろまで長く続いた（図 3)．その後，音楽と科学が切 り離される。そして，現代は再び，科学的音楽研究の再

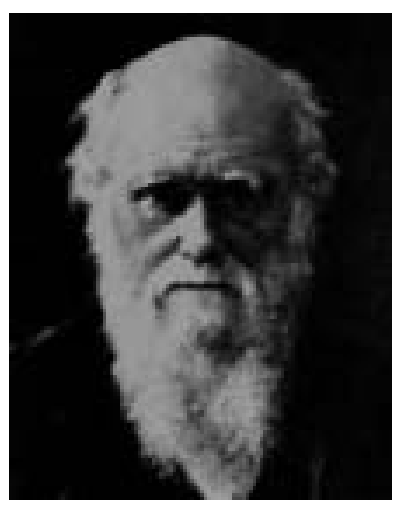

図 2 ダーウィン

\begin{tabular}{|c|c|c|c|c|c|c|}
\hline $\begin{array}{l}\text { ギリシア·ローマ } \\
\text { 時代 }\end{array}$ & 中世 & \begin{tabular}{|l} 
ルネサンス \\
時代
\end{tabular} & $\begin{array}{l}\text { バロック } \\
\text { 時代 }\end{array}$ & $\begin{array}{l}\text { 古典〜ロマン } \\
\text { 主義、ほか }\end{array}$ & 20世紀 & 21世紀 \\
\hline
\end{tabular}


興の時期と言える。この流れで最初に登場したのが，ピ タゴラスであり, ギリシアの 3 大哲人にも影響を及ぼし た。

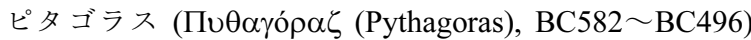
は, 直角三角形の定理を発見した数学者として広く知ら れている。また，彼は哲学者から音楽家でもあった。歴 史上自ら初めて [哲学者] と名乗り,「数・宗教・音楽, すべてはリズムである」とも語ったという，弦を張って 弾いて音を出して研究し（図 4)，私たちがいま使ってい るドレミの音階を発見したのだ（図 5).

ピタゴラスは次のように述べたという．「天空の宇宙に は妙なる音楽が流孔ているが, 通常の人には聴こえない。 しかし，心が浄化されていれば聴こえる」と．そして， 自身が，人の心身を調和させる音楽を作曲して弟子に聴 かせ，心を清める生活を指導したとされる。它を清らか にするのが重要であり，心を滅すれば心の調和が訪れる と説いた。いかにも東洋的と言えよう。

一方，アリストテレスは，悲しいときには泣くなど， 鬱積した感情や葛藤を表現してもよいと述べた。 そのと きの心と同調させるように振舞えば，心の調和が回復す
ると論じたのである. いかにも西洋的である.

この考光方が，音楽療法の領域で受け入れられている 「同質の原理 (Iso Principle)」に導かれていく. 具体例とし て，映画や演劇で悲劇のストーリーに接すると思わず泣 いてしまう。しかし，涙を流した後には清々しく感じな いだろらか？つまり，心の状態と同質の振舞いによっ て，ストレスから開放され，心の浄化，つまりカタルシ

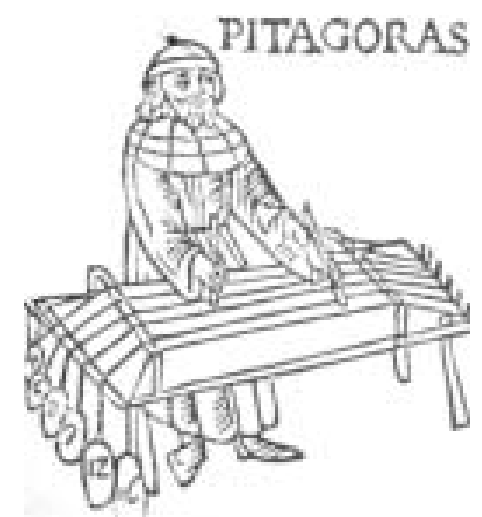

図 4 弦の張力と音程の和を研究するピタゴラス（音楽理論書 挿画 15 世紀）

\section{৫コラム}

\section{アリストートルとプレイトー}

本稿で出てきたアリストテレスとプラトンについて, 言語学の立場から, 話題提供したい.

まずは，アリストテレスから．英語では Aristotle ['ア リス，トトる]（'の次をアクセントとして読む）と sが 消失している. 本来, 古典ギリシャ語では A Aristotélēs［アリスト'テれース］であり，ラテン語で はAristotelēs［アリス'トテれース］となった。その後, 各国の言語を含むロマンス語で変遷を受け,特にフラン 又語で語尾が変化していく，教養語と民衆語が融合し， 極端に言葉が擦り切れてしまらからである.フランス語 の雲囲気やリエン゙ンから，何となく推測できるだろう． 結局, 英語ではアクセントが頭に来て, 弱い語尾はなく なってしまったのだ.

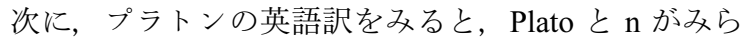

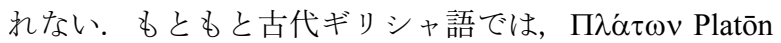
[プ!らトーン］であり，平らな人，幅の広い人といら 意味も含まれていた。関連語には $\pi \lambda \alpha \tau v \zeta$ platys [プら テュス（平らな, 幅広い) があり, 医学や生物用語に platy-（扁平）が使われている.

彼の立派な体躯に因んで,「プラトーン二幅の広い者」
と呼んだのが起源であるとか,「雄弁さ」「額が広い」と いら意味であるとか, 諸説がみられる. ラテン語の時代 には, Platō [プ!らトー］とnが省略されつつある.

言葉とは変遷を受けるものであり, 語尾の $\mathrm{n}$ は, 落ち たりついたりする，その一因は，語尾の $\mathrm{n}$ (ン）とか $\mathrm{m}$ （ム）は変化を受けやすいからである。たと党ば，動物 のライオン (lion) とジャングル大帝レオ (leo) の語源は 同一だ．ラテン語では，Leō（'れオー，主格，ライオン が), leōne（れ'オーネ, 奪格, ライオンから）といら 文法があり, 各言語に影響していく.つまり, leone [れ 'オーネ）中世ラ, leone [れ'オーネ]伊, león［れ'オ ン］西, leão [れ'アオん] ポルトガル, lion [り'ヨん] 仏, lion ['らイアン] 英, などがみられる。レオーネと は，車の名前に使わ机ているのをご存知であろう。

な抒，フランスには，大都市のリヨン (Lyon), リオ ン (Riom) 郡, リオン (Lion) 湾, ライオン (lion) など, 紛 らわしい言葉が多い、打酒落なカフェに使う名前「ル・ リオン」には，いろんな意味が含まれる。このように， 酒脱で报もしろく進化する言葉に，乾杯したい． 


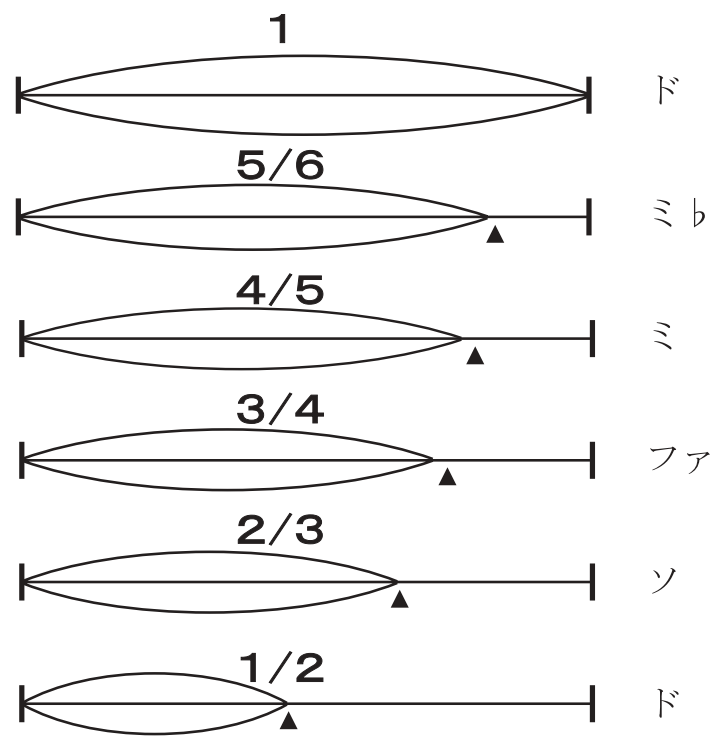

図 5 ドレミの音階はピタゴラスが発見

張力が同一で，弦の長さを 1 の音程をドとする．図の下から順 に, 長さが $1 / 2$ で振動数が 2 倍となり， 1 オクターブ上のドとな る. 長さが $2 / 3$ で振動数が 1.5 倍となり, 音程はり。長さが $3 / 4$ で振動数が 1.333 倍でファ. このように, 整数比で純正律の 12 音階が形成される。ただし，通常の鍵盤楽器では，どの調から 演奏しても同様の音階となる必要があるので，振動数を微調整 して 12 音の平均律で調律している. 各鍵盤の振動数は等比数列 で約 6\%ずつ高くなる. 1.06 の 12 乗がほとんぞ 2.0 に近似する。

スになるというものだ. 同様に，音楽を聴いたり歌った りする場合に打いても，そのときの気分や心の状況に近 い曲を選ぶとよい，逆に，心が落ち込んでいるときに快 活な曲を急に聴いても，心は聞きたくないと拒否してし まう。その理由は，あまりに，異質すぎるからである。 心を和ませながら曲調を次第に変えていくとよい，

\section{3. 音と音楽}

「音」の定義はわかりやすい，音は自然に存在してお り, 物理的, 自然科学的な事物で過程である. 音は物質 の振動で伝わり，空気の分子の振動（音波）を利用して 伝わっていく．純粋に物理学的な存在と言光る.

一方，「音楽」を定義するのは難しい，音楽事典をみて も明確な音楽の定義はなく, 広辞苑（第四版）では，「音 による芸術．拍子・節・音色・和声などに基づき種々の 形式に組み立てられた曲を演奏するもの」と，音楽は人 の社会に存在して扮り，文化的，社会科学的な事物で過 程でもある，以上ょり，音楽とは，自然科学拉よび社会 科学の両者の間に存在している1).

古くから，音楽が健康にプラスとなるエピソードが紹 介されている，古代エジプト人は音楽を「魂の医者」と
呼び，古代ギリシアでは，楽曲の旋律や楽器の旋律が人 の情緒や魂を興奮・陶酔，平静・安定をもたらすと信じ られていた．歴史的著名人として，エジプトのイムホテ， ギリシアのアスクレピオス，ヒポクラテス，ガレンなど 医学の創始者たちが，スポーッや遊び，乗馬，農耕作， 仕事などと同様に，心身の調和のために音楽を処方した とされる3)

\section{4. 音楽療法とは}

音楽療法（Music Therapy（英）, Musik Therapie（独）, Musico Therapie（仏））の定義は，「音楽のもつ生理的， 心理的，社会的働きを用いて，心身の障害の回復，機能 の維持改善, 生活の質の向上, 行動の変容などに向けて, 音楽を意㘡的, 計画的に使用すること」（日本音楽療法学 会) ${ }^{4)}$ となっている.

全米音楽療法協会の定義を示す. Music therapy is the use of music in the accomplishment of therapeutic aim: the restoration, maintenance, and improvement of mental and physical health. It is the systematic application of music, as directed by the music therapist in a therapeutic environment, to during about desirable changes in behavior.

音楽療法がカバーする領域は非常に幅広い，その目的 として主なものは次のと扤りである。

(1)心身の健康確保と疾病や障害の予防

(2)心身の健康増進や健康の創造

(3)疾病や障害の治療

(4)心身の機能改善

(5)クライアントの QOL の向上

(6)終末期医療の場での応用，なぞ

レクリエーション的に広義の意味で用いることもあれ ば, therapy の一つとして狭義に使ら場合もみられる。療 法といら点からみた分類を示してみよう。

(1)ストレス・ケア

(2)ホメオスターシスの回復

(3)自然治瘉力の促進

(4)疼痛緩和

(5)緊張緩和

(6)免疫・防御力の増進

(7)教育効果の援助

(8)情緒・精神の安定

9治療関係の提供

また，場所といら切り口でみた分類も可能である.

(1)ペイン・クリニック

(2)胎教・出産

(3)歯科治療 
(4)透析治療

(5)リハビリテーション

(6)心身障害の療育

(7)老人医療

(8)ターミナル・ケア

(9)病院内のより良い環境の提供

以上のように，治療手技に活用できるのは，音楽だけ が持つ特性による，その特性を下記に示す。

(1)音楽は知的課程を介さず, 直接情動に働きかける

(2)音楽活動は，自己愛的満足をもたらしやすい

(3)音楽は, 人間の美的感覚を満足させる

(4)音楽は発散的で，情動が発散する方法を提供する

(5)音楽は，身体的運動を誘発する

(6)音楽は，コミュニケーションである

(7)音楽は, 一定の法則で構造化されている

(8)音楽には多様性があり，適用範囲が広い

(9)音楽活動には，統合的精神機能が必要である

(10)集団音楽活動では，社会性が要求される

音楽療法の全体像を図 6 亿まとめた。 アプローチ法と してシュワーべ (Schwabe, C. H) は2 種に大別している.

1) 受容的音楽療法 (receptive music therapy) : 音楽を聴 くことによって，情緒・行動の変容を目的としたものを いう。，心身のリラクセーションやさまざまな機能回復を 目指す，音楽聴取による効果が研究されている．本人が 好みの音楽を選ぶ場合，その種類にかかわらず，颃括む 衩身体の緊張が軽快し，身体表面の毛細血管が拡張して 皮膚の温度が上がるという。医療や福祉現場で，重篤な

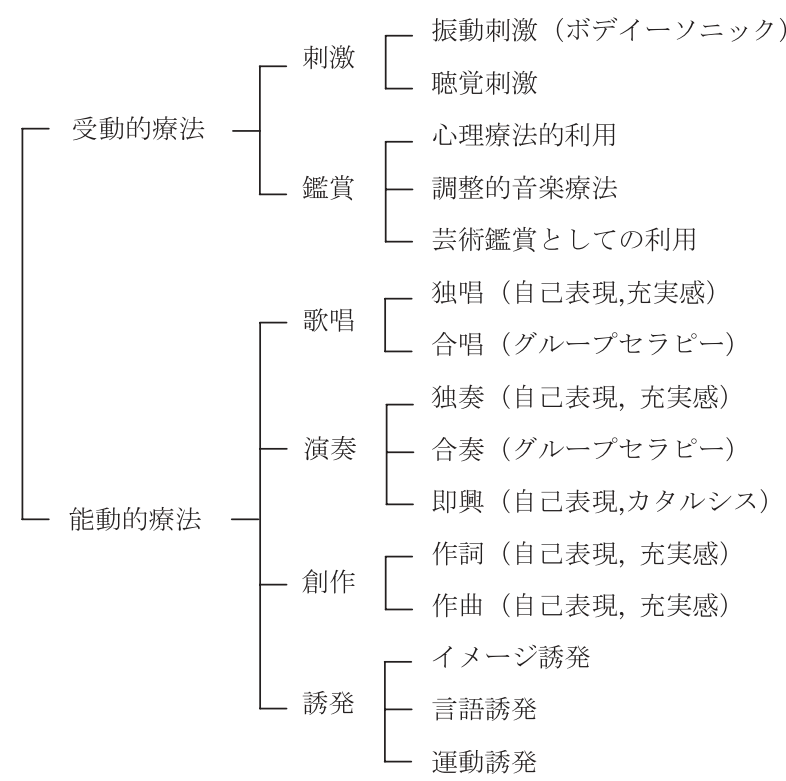

図 6 音楽療法の全体像 3) を改変
病態を有する人には, 訓練の第一歩として使われている.

2) 能動的音楽療法 (active music therapy) : 歌唱や楽器演 奏・創作など，自らが活動する音楽活動を通して行うも のである. 受容的音楽療法に比べて, 種々の改善や向上 が期待される. この中で最も有名で普及しているのがカ ラオケだ．日本が世界に誇る代表的な音楽文化であり， 空（から）の，オーケストラ（オケ）といら意味である. 日本人はカラオケを好む傾向があり，上手に活用すれば， 臨床現場でも効果が期待できる.

\section{5. 欧米の音楽療法}

音楽療法は, 戦争の際, 軍隊に抢ける士気の高揚や傷 病兵の慰問に用いられ，効果が見出された歴史がある5). 近代の音楽療法の始まりは，1940 年に米国で音楽療法 コースの開設からである. 1950 年には全米音楽療法協会 が，1958 年に英国，1959 年にオーストリア同協会が設立 された。

先端的な状況にあるのは米国で，さまざまなスタイル の音楽療法が医療で行われている，小児科，精神科，心 療内科，老人科，リハビリテーション科，神経内科，外 科，ER，ICU， NICU，緩和医療などである6)。特に米国 では，認定音楽療法士 (registered music therapist, RMT) が 小児に関わる事例が多く，その対象疾患を次に列挙する77. 頻度が高い順に，発達障害，行動障害，情緒障害，身体 障害，学齢期の览童，重複障害，言語障害，自閉症，視 覚障害, 神経学的障害, 聴覚障害, 物質関連障害, 虐待, 性的虐待，幼児，重複診断，頭部損傷となる。米国では 民間の医療保険が導入されている現状がある。保険会社 が了承すれば音楽療法に保険給付される. RMT の多くは 個人でオフィスを持ち，医療の場以外でも療法を行って いる6).

英国や北欧では福祉領域が主とした領域で，ドイッで は精神科領域で心理療法の一つとして音楽療法が適用さ れている6).

\section{6. 日本の音楽療法}

本邦では, 1960７0 年代から音楽療法に関する活動が 始まり，1986 年日野原重明氏が日本バイオミュージック 研究会（後に学会）を設立した，その後，臨床音楽療法 協会と統合し, 全日本音楽療法連盟が 1995 年飞誕生. 1997 年から音楽療法士の資格認定が始まり, 2001 年日本 音楽療法学会が発足した. 現在, 会員数は 6500 名に増加 し，学会認定の音楽療法士は 2007 年 3 月で 1308 名とな り，全国で活動している. 
日本で，広義の音楽療法のフィールドは，拈括むね保 健，福祉，教育，医療という4 つの分野に分けられる. また，対象者によって分類すると，高齢者（認知症を含 む)，精神疾患（統合失調症など），知的障害者（児童を 含む)，さまざまな疾病を有する対象者，打よび健康な成 人・高齢者となろら。

音楽療法が適用される疾患や場合を次に示す8).

(1)疾患の補助的治療

心身症拈よび関連疾患

本態性高血圧，気管支喘息，慢性胃炎，消化性潰瘍， 過敏性腸症候群，狭心症，陳旧性心筋梗塞，偏頭痛， 緊張性頭痛，慢性関節リウマチ，神経性食欲不振症， 神経性過食症など

神経症，らつ状態，不眠症

更年期障害

精神分裂病

ストレス関連性障害，疼痛，不定愁訴

不安・緊張により悪化する身体疾患

(2)疾患のケアおよびリハビリテーション

児童期：不登校，自閉症，精神遅滞，視覚障害，聴覚

障害，多動性障害など

老年期：老年期痴呆など

リハビリテーション:麻痺の改善, 肺手術後の呼吸練習

ターミナル・ケア

(3)予防医学

心身のリラックス

感情のコントロール

緊張・夏らつ・怒りなど

特殊な状況での不安の軽減

手術室，歯科治療，透析など

音楽療法が有効な理由を次にまとめてみよう99.

(1)音楽は知的過程を介さず，情動に直接働きかける。 そ のため, 認知症高齢者や知的障害者にも有効である.

(2)音は優れたコミュニケーション機能を有する。言葉が 不自由な対象者の心も音楽で開くことができる.

(3)リズムは, 運動性を備えている. 音や音楽の存在によっ て身体運動を誘発しやすい.

(4)音楽には，心を浄化するカタルシス作用を有する。抑 圧された感情の発散に役立つ.

(5)音楽によって自己表現が可能である．音楽の活用で心 を発散させ，達成感や満足感をもたらしやすい，

6集団セッションでは合唱や合奏を行う。他人への配慮 や自己責任に気づき，協調性や社会性を養ら。

現状で，頻度が高い対象者は高齢者であるので，引き 続き，説明を加えてみたい

\section{7. 高齢者に対する音楽療法}

\section{(1) セッションの概要}

音楽療法士はさまざまな TPO で音楽療法セッション を行う（図 7)。高齢者に対する音楽セッションの標準的 プログラムの流れを示す6)

(1)始まりの歌（導入）

(2)仮称（身体と感情の発散）

(3)ゲーム（他者を認知）

(4)合奏（コミュニケーション）

(5)音楽鑑賞（リラクセーション）

6)体操（クーリングダウン）

(7)打別れ・再会の歌（終了）

本邦では高齢者施設に拈ける集団セッションの頻度が 高い。 その有効性の理由を列挙する.

(1)希望の存在 instillation of hope

(2)普遍的体験 universal experience

(3)受容の体験 accepted experience

(4)愛他的体験 altruistic experience

(5)情報の伝達 imparting of information

6)現実の検討 reality orientation

(7)模倣と学習 imitate, learn

(8)カタルス catharsis

(9)相互の作用 interaction

(10)共有の体験 common experience

(11)実存的体験 existential experience

高齢者セッションでのコッがある10).「歌は世につれ， 世は歌につれ」といら．歌が流行ったときの演歌や流行 歌は，当時の時代背景と共に存在し記憶されている. ク ライアントが記憶障害がある認知症であっても，歌なら

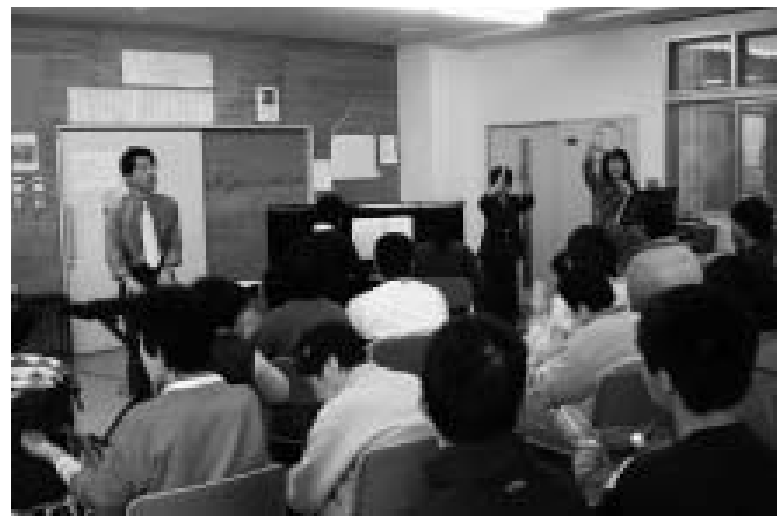

図 7 音楽療法セッションの光景

音楽だけではなく，言葉のコミュニケーションで五感を刺激し， タンバリンでリズムを誘導する. 認定音楽療法士 2 名で担当 (左 は筆者，右は吉岡明代氏). 
しっかり間違わずに歌える場合が少なくない，歌いなが らその曲を覚えた頃，家族，友人，学校，近所の情景な ぞ，記憶が呼び戻される．歌がきっかけとなって五感も 刺激され，会話も弾み，脳が活性化される。

\section{(2) 評価が必要}

単にセッションが楽しいといらだけでは，療法と言え ない. 音楽療法とされる本質は, 「治療を達成するための 音楽活動, もしくは音楽の科学的応用である」という ${ }^{11}$. 音楽療法セッションの前後で，きちんとした評価が必要 であろら．対象者の認知レベルや身体面，精神面を把握 しておきたい，きちんとした評価で，連携職種と共通理 解が進み，現場の業務がスムーズとなる，成人〜高齢者 に有用な評価スケールを下記に示す。

(1)HDS-R 改訂長谷川式簡易知能評価スケール 認知症スケールとして繁用，1991 年改訂で 9 項目

(2)MMSE (Mini Mental State Examination) 認知症スケール，信頼性・妥当性高く 11 項目

(3)GDS (Global Deterioration Scale) 認知の進行程度を, 患者面接と介護者から評価

(4)FIM (Functional Independence Measure) 運動 ADL 13 項目, 認知 ADL 5 項目を 7 段階評価

(5)POMS (Profile of Mental States) 6 つの領域の感情を数値として評価，65 項目

(6) The Mood Checklist Short-form 1 (MCL-S1) ${ }^{12)}$ 快感情，リラックス感，不安感の下位尺度を評価 また，セッションが有意義であったのかを評価するた め，下記の 18 項目をチェックするとよい13).

(1)認知・遂行：活動内容の理解，取り組み, 注意・集中, 問題の対処, 変更の対処

(2)感覚・運動：移動機能，姿勢保持，身体的耐久性 目的動作の協応性，感覚機能

(3)心理面：ストレス耐性，感情のコントロール 音楽活動への興味関心，意志・意欲

(4)社会技能 : 参加・交流，基本的配慮 表現・意思表示，協調性

\section{(3) 高齢者での効果}

高齢者に打ける音楽療法の効果が報告されている. 6393 歳の高齢者 30 例飞毎日 25 分間 4 週間音楽を聴取. 聴 取群では収縮期血圧が $11.8 \mathrm{mmHg}$ 有意な下降がみられ, 対照群では変化がなかった ${ }^{14)}$. 認知症の高齢者 125 例に 2 週間連続で毎日セッションを実施. 前後でMMSE (Minimental State Examination) で評価すると，見当識（時間, 場所), 記銘, 復唱, 読字, 想起の項目で有意に改善した ${ }^{15)}$. アルッハイマー病患者 28 例に快活な $\mathrm{BGM}$ 音楽を聴取さ
せると，好ましい動作が増加し，興奮など好ましくない 動作が減少した ${ }^{16)}$.

能動的活動は高齢者の心身にプラスとなり，カラオケ に加光, 楽器の導入もよい. 市江は管楽器（リコーダー, サックス) を推奨している ${ }^{17)}$. 鍵盤楽器に比べ習得が比 較的容易で，心肺への適度な負担や，練習内容や人前て 披露する機会を考光ると確かに適度であるら。

(4) 言語トレーニング

高齢者は脳血管障害により，片麻痺や言語障害を呈す る。言語トレーニングの際に音楽を活用することで，よ り良い効果がみられる。その手法と説を記載する。

(1)メロディとイントネーションによる訓練 (melodic intonation therapy, MIT)

(2)音楽による発話刺激

(Music Speech Stimulation, MUSTIM)

(3)リズムによる発話合図

(Rhythmic Speech Cueing, RSC)

(4)音声抑揚療法 (Vocal Intonation Therapy, VIT)

(5)療法的歌唱 (Therapeutic Singing, TS)

(6)口頭運動呼吸トレーニング

(Oral Motor Respiratory Exercise, OMREX)

(7)言語発達・発話トレーニング

(Developmental Speech and Language training through Music, DSLM)

(8)音楽による象徵的意志疎通トレーニング

(Symbolic Communication training through Music, SYCOM)

音楽療法士は言語療法士とも協調しながら，患者 (client) に応じたトレーニングを行っていきたい.

(5) パーキンソン病に規則的リズムの音

パーキンソン病には，安静時振戦，固縮，無動，姿勢 反応障害がある. 歩行が特徵的で，姿勢の立ち直り反応 が悪く，押された方向に突進してしまう。同患者の歩行 練習で, 規則的な音の聴取による歩行の改善がみられる. 動作の 3 次元解析法なぞの先端技術が導入されてい $3^{18)}$.

\section{8. 補完代替医療における音楽療法}

\section{（1）補完代替医療の併用}

近年は，補完代替医療の中で，音楽療法と他の療法と の併用が試みられつつある. 主なものを示す。

(1)自律訓練法 :

心身症の治療で頻用される方法 
リラクセーションに役立つ選曲が必要

心気症，心臓や呼吸，胃腸の神経症など機能性障害

(2)バイオフィードバック療法 :

緊張性の頭痛などに対して適用

音楽と筋電図のフィードバックを用いて治療

(3)アロマセラピー :

人間の臭覚を利用したリラクセーション効果

心身症の治療法の一つとして有用

(4)情動イメージ体験 :

各自の心の中でイメージ描出

(5)絵画療法 :

両者を併用することで導入がより容易

救急室勤務のナースに音楽十アロマセラピーを 12 週 間ずつ夏と冬に行い，施行群と対照群とで不安度を比較

し，効果を検討した報告がある ${ }^{19}$.

\section{(2) アントロポゾフィー音楽療法}

補完代替医療的な観点から，興味深い考方方を紹介し たい，音楽が人を癒すのは体験的にわかっていたが，体 系的な医療法として理論化したのが，ドイッの教育学者 ルドルフ・シュタイナー (Rudolf Steiner, 1861-1925) であ る. 哲学博士かつアントロポゾフィー（anthroposophie, 人智学）の創始者で，シュタイナー教育が有名だ. 彼が 提唱したのがアントロポゾフィー音楽療法である.

その中から彼の主張を記載してみよう。人と音楽とは 関連があり，頭脳の働きはメロディ，呼吸はハーモニ一， 手足の運動や血液循環, 物質代謝はリズムに該当する. 病気とは，これらの 3 者の要素の乱れにより引き起こさ れるという，例として，喘息患者は，呼吸がうまくでき ず，また手足の筋肉が弱くなる。そのため，リズミカル な音楽で呼吸りズムを整え，手足を動かして筋肉を増強 させるとよいと考光る。らつ病の患者では，常に気持ち が暗く沈んで抢り，動作もゆっくりと緩慢である。そこ で，アクセントをつけた音楽を聴かせると，次第に心が 明るく開けてきて，気分も良くなるとされる。

\section{(3)トマティス・セラピー}

ほかに，音楽療法の一種とされる聴力・聴覚療法とし て, フランスのアルフレッド・トマティス博士が提唱す る「トマティス・セラピー」がある。彼は，エネルギー 発生が，蝸牛管の中にある感知細胞であるコルティ細胞 に関係していると主張した。コルティ細胞は，低音域， 中音域，高音域で分布が異なる。

(1)低音域ゾーン $(125-1000 \mathrm{~Hz})$ : リズム感やスポーツに抒 ける身体イメージ，時間的空間的概念に関与する音域 (2)中音域ゾーン (1000-3000 Hz) : 音感や記憶力, 表現力,
コミュニケーション能力に関与する音域

(3)高音域ゾーン $(3000-8000 \mathrm{~Hz})$ : 知的能力, 芸術性, 想 像力, 発想力に関与する音域

3 音域でその比率が $100: 500: 24000$ であり, 感知細胞 が高音域を担ら領域に集中して扣り，頭脳を活性化する のは高音域であるといら 20 .

\section{9. 経済的指標からみた音楽療法}

いま音楽療法士の現状をみると，セッションの報酬だ けでは生活がなりたたない，そこで，音楽療法の経済的 側面の議論が高まりつつあり，高野は音楽療法ビジネス の可能性について論じている ${ }^{8)}$. 昨今，音楽療法が注目 され，日本で音楽療法を学ぶ学校は 65 校あるといら。こ のブームまたはバブルは，多くの大学や専門学校が，経 営のため無理を重ねてしまったのが一因と考学られる.

毎年，音楽大学や短大，専門学校の卒業生が 5 万人あ り，音楽のスキルを有していても受け皿がない。そこで， 音楽的能力を活かすため，音楽家の人材派遣会社も現れ た。需要と供給のバランスによる経済原理があてはまる だろらか？コンビニの仕事ではなく，長年にわたる研 修と研鑽が必要な専門職である。音楽療法士の資格があ れば仕事があるのではなく，資質と実力が重要だ。最初 はボランティアでも，クライアントから実力や人望を認 められ信頼感が生まれれば，生業としての可能性も出て くる. 全体的な議論は難しく，個別の対応となるだろう．

このような風潮には，長所もあれば危惧もある。「医療 はアートであり，ビジネスではない」，「ボランティアの 原点を忘れるべきではない」といら判断もあり，今後， 日本音楽療法学会の方向性や国の対応もみながら，ビジ ネスモデルの経過を観察していきたい.

\section{0. 行政からみた音楽療法}

\section{(1) 音楽健康法と音楽療法}

行政は，音楽療法について幅広い分野に関与できる ${ }^{22)}$ (図 8).この中で高齢者に関して，わが国で 65 歳以上の 人口は 2005 年に $21 \%$ に到達し，世界でも最高の高齢化 国家となった。これに対して，全国の都道府県では在宅 支援活動が継続中だ。多くが自立，要支援のレベルであ り，要介護 $1 \sim 2$ 程度までが事業を利用できる。

高齢者は，注核健康な群と，認知症を含む疾病を有す る群とに大別される．高齢者の認知機能が低下する順序 は，最初が言語，続いてハーモニー，メロディ，リズム になるという。これらを参考とし，民間との有機的なネッ トワークを築けば，行政が有益な音楽療法講座を企画で 


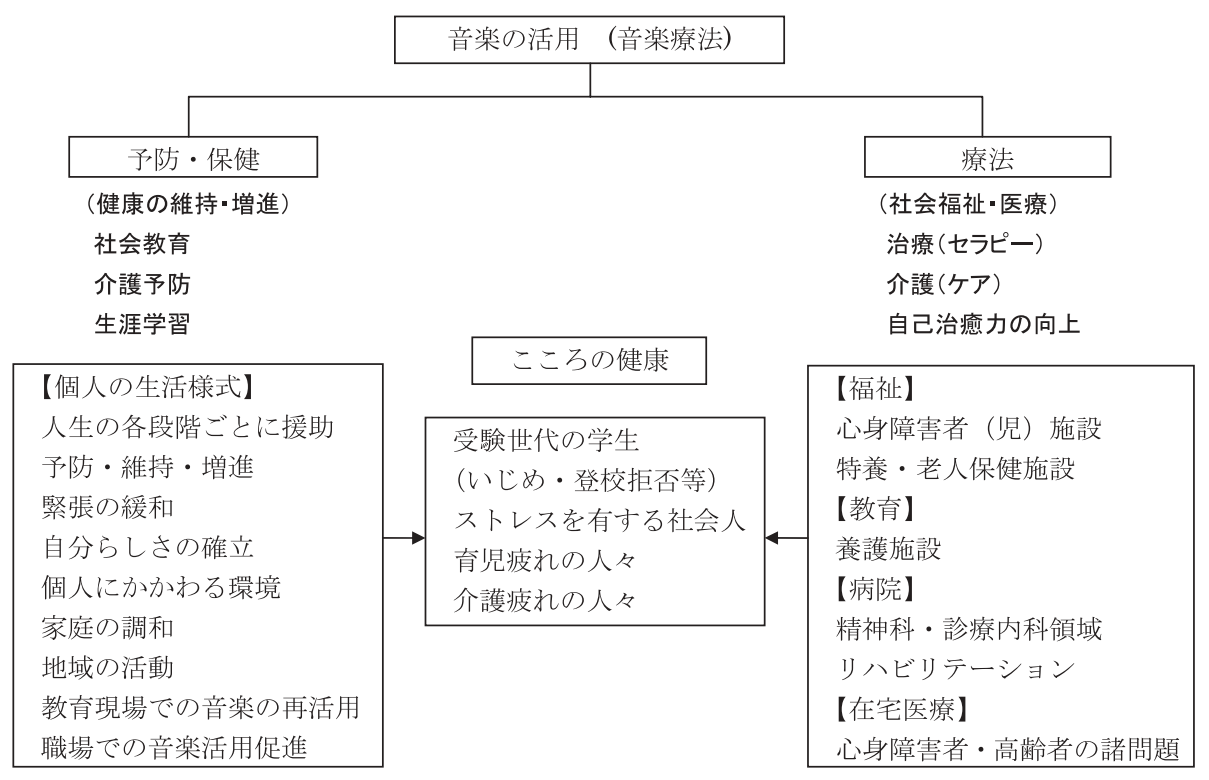

図 8 人々の医療福祉に対する音楽活動

き，音楽健康法または音楽療法を進められるだろう。

\section{(2) 音楽療法士の資格}

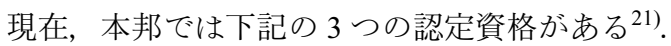

(1)認定音楽療法士: 日本音楽療法学会 (2001 年以前には, 全日本音楽療法士連盟）による認定資格である，国家 資格まで暫定的な資格といら位置づけによって，平成 9 年 3 月から年に 1 回試験が実施されている。知識や 音楽技術，臨床経験などが必要となる4).

(2)音楽療法士 1 種， 2 種：全国音楽療法士養成協議会に よるものである. 平成 12 年, 音楽系大学拈よび短期大 学関係者によって, 音楽療法を行う人材の養成目的で 設立された団体である，各規定された音楽療法士養成 課程を有する大学あるいは短期大学（認定校）に入学 する. 所要単位数の習得により, 4 年制で 1 種, 2 年制 で 2 種の資格が得られる。

(3)自治体による認定資格：岐阜県, 奈良県, 兵庫県の 3 県で，独自の研修や認定方法が規定されており，自治 体による認定が行われている.

以上を把握し，各県の行政でも音楽療法士が最大限に 活用されることが望まれる.

\section{(3) 音楽振興法}

1994 年に制定された法律として，「音楽文化の振興の ための学習環境の整備等に関する法律 (音楽振興法)」が ある. 主に教育分野であるが, 医療の関わりが久られる。 本法律の推進のため, 生涯学習音楽指導員といら資格制
度が始まり，1400 名が資格を取得している. その活動は, 小児や高齢者，障害児，高齢者施設入居者まで含み，約 3 割の指導員が日本音楽療法学会にも所属している6).

今後, 医療・音楽・教育・行政が手を携兄て音楽療法 の企画を進めていけば, 健康や医療, 福祉だけではなく, 本法律の第 1 条に記されているように, 「世界文化の進歩 及び国際平和に寄与する」できるだろう.

\section{おわりに}

本稿では, 音楽療法について, 関連領域を含め補完代 替医療の見地から種々の情報を提供した，近年，本分野 の書籍は増加して扮り，著者の HP にも同分野の論文を 多く公開しているので参考にされたい23).

今後, エビデンスに基づくデータを集積し, evidencebased music therapy を進めていくとともに, 各クライアン トに応じた narrative-based music therapy についても合わ せて研究していくべきであろう。これが車の両輪となれ ば，サイアンスとアートが調和を保ちながら，バランス よく進化していくことができると思われる.

\section{参 考 文 献}

1) 福井 一. 音楽の生存価. 音楽友之社, 2005 .

2) 岩田 誠. 文字の脳科学一過去・現在・未来. 週刊医学界 新聞. 2007; 2757(2007.11.19): 1-2. 
3) 山根 寛. ひとと音・音楽〜療法として音楽を使う〜. 青 海社. 2007.

4) 日本音楽療法学会. http://www.jmta.jp/.

5) Sullivan JM. Music for the injured soldier: a contribution of American women's military bands during World War II. J Music Ther 2007; 44(3): 282-305.

6) 市江雅芳. 音楽と人間との新しい関わり〜音楽療法とその 周辺〜。 バイオメカニズム学会誌. 2006; 30(1): 26-30.

7) 高野安子. 音楽療法ビジネスの可能性. 新風舎. 2007.

8) Bando H. Music therapy. Asian J Medicine 2001; 44(1): 30-35.

9) 貫 行子. 認知症発症のメカニズムと予防・改善プログラ ム. PGnet 2007; 54(4): 18-21.

10) 関谷正子. 高齢者の音楽療法が認知機能と感情に及ぼす影 響. 札幌大谷短期大学紀要. 2007; 37: 67-76.

11) Carter S. Music therapy for handicapped children. Brown $F$ and Eagle C (Eds). Mentally retarded. Project Music Monograph Series. Washington, DC: National Association for Music Therapy. 1982.

12) Nabetani $T$, Tokunaga $M$. The effect of short-term (10- and 15min) running at self-selected intensity on mood alteration. J Physiol Anthropol Appl Human Sci 2001; 20(4): 231-239.

13）小坂哲也. 音楽療法に拈ける評価について一七ッション評 価表の作成を中心に一. 広島国際大学医療福祉学科紀要. 2007; 3: 13-20.
14) Teng XF, Wong MM, Zhang YT. The effect of music on hypertensive patients. Eng Med Biol Soc 2007; 1: 4649-4651.

15) 渡辺恭子. 音楽療法が痴呆症状を呈する老年期患者の認知 機能に及ぼす効果に関する考察. 日本音楽療法学会誌. 2002; 2(2): 181-187.

16) Ziv N, Granot A, Hai S, et al. The effect of background stimulative music on behavior in Alzheimer's patients. J Music Ther 2007; 44(4): 329-343.

17）市江雅芳．音楽でウェルネスを手に入れる．音楽之友社. 2007.

18）美原 盤，藤本幹雄，美原淑子，パーキンソン病患者の歩 行障害に対する音楽療法の効果. (第 1 報, 第 2 報) 日本音 楽療法学会誌. 2005; 5(1): 58-71.

19) Cooke M, Holzhauser K, Jones M, et al. The effect of aromatherapy massage with music on the stress and anxiety levels of emergency nurses: comparison between summer and winter. J Clin Nurs 2007; 16(9): 1695-1703.

20) 池田芳幸. 生徒の心の安定をはかる校内の「音環境」の改 善と整備. 教育実践研究. $2007 ; 17: 175-180$

21) 斉藤里果. 音楽療法の紹介. 理学療法科学. 2006; 21(4): 453457.

22）岸 覚永. 未来型福祉のかたち〜生きがいら゙くり，健康づ くりの音楽療法〜。地方自治職員研修. 2006; 549: 66-69.

23) http://hb8.seikyou.ne.jp/home/pianomed/

\title{
ABSTRACT
}

\section{Current Status of Music Therapy}

\author{
Hiroshi BANDO ${ }^{1,2}$ \\ ${ }^{1}$ Japanese Music Therapy Association, boardman \\ ${ }^{2}$ The Japanese Society of Anti-Aging Medicine, boardman
}

Currently, music therapy (MT) is a focus within complementary and alternative medicine (CAM). MT is divided into two categories: recreational music (covering a broad field) and medical music therapy. It is not sufficient that the patient simply feel better; the evaluation methodology itself should be improved. MT can also be categorized as passive (ie, listening) and active (singing and/or playing instruments). Common MT subjects in Japan are infants, patients with psychiatric disorders or dementia, and the aged. Recently, combination therapy of MT and other CAM therapies has become more common and is gaining official recognition at a policy level. As MT is further developed, it is expected to play an increasingly important role in CAM in the future. Research in evidence- and narrative-based MT is also expected to progress.

Key words: music therapy, Complementary and Alternative Medicine (CAM), rehabilitation, the aged, dementia 